\title{
FALLECIMIENTO DE MARCELINO VILLEGAS
}

El 18 de febrero de 1991 fallecía en Madrid el Dr. Marcelino Villegas González. Profesor titular de Estudios Árabes e Islámicos de la Universidad de Alicante, colaborador y miembro del Comité de Redacción de la revista SHARQ AL-ANDALUS. ESTUDIOS ÁRABES. Deja entre sus amigos y colaboradores un hueco irremplazable.

Marcelino Villegas había colaborado en la revista cuando aún era profesor de la Universidad de Orán, antes de incorporarse a la Universidad de Alicante. A partir de 1987 y del volumen 4, tomó parte muy activamente en su Comité de Redacción, con el entusiasmo que ponia en las actividades científicas del Departamento y en sus publicaciones. También colaboró con un libro, póstumo, de la Colección «Xarc Al-Andalus», sobre su autor preferido de estos últimos años, el Premio Nobel egipcio Naguib Mahfuz: La narrativa de Naguib Mahfuz. Ensayo de sintesis. Tenía en preparación otro libro para esa colección, sobre narrativa argelina contemporánea.

La revista "Awrâq» de Madrid, de cuyo Comité de Redacción formaba parte también, le prepara un volumen de homenaje. En espera de éste y de otros estudios sobre su obra científica, docente y de crítica literaria y cinematográfica, la revista SHARQ AL-ANDALUS. ESTUDIOS ARABES quiere manifestar cuánto lamenta su pérdida y publicar la lista de sus colaboraciones en las páginas de sus volúmenes, incluido este número 8 (1991) que él no verá impreso.

Vol. 3, 1986: «Situación de la narrativa argelina», pp. 69-80.

Vol. 4, 1987: «¿Influencias o lectura crítica? Naỹ̄b Mahfūẓ y 'Abd al-Hamìd lbn Hadūqa», pp. 83-92.

«Un enigmático término cervantino», pp. 249-252.

Dos cuentos de Mahdi Tsà ș-Ṣaqr, pp. 263-256.

Recensiones:

Madhĩ Tsà ș-Ṣaqr, Hayrat sayyida 'ayūu wa-qișaș ujrà, pp. 367-368. 
'Umar ad-Daqqāq, Funun al-adab al-mu'āṣir fi Suriya, pp. 369-371.

Vol. 5, 1988: «Narrativa árabe, otra interpretación», pp. 111-128.

Un texto de Al-'Aqqād (1889-1964) sobre Blasco Ibáñez, pp. 221-229.

Libros publicados por miembros del Comité de Redacción de la Revista en 1988, pp. 231-234.

Recensiones:

Thoraval, Yves, Regards sur le cinéma égyptien. Nouri, Shakir, A la recherche du cinéma irakien, pp. 251-254.

Aṣ-Ṣaqr, Mahdi, \%sà, aš-Šāhida wa-z-zany̆, pp. 254-256.

Weber, Edgar, Le secret des Mille et une Nuits, pp. 256-257.

Naýib Maḥuzu, Premio Nobel 1988.

Vol. 6, 1989: «Personajes españoles en la narrativa argelina», pp. 103-113.

«Zakariyyā Tamir once años después», pp. 195-196.

Recensiones.

Hasan Al-Bandārì, Fann al-qișșa l-qasira inda Naȳib Mahfuz, pp. 255-260.

Vol. 7, 1990: «Cuentos semiinéditos de Naỹīb Mahfūẓ», pp. 55-68.

Dos cuentos de Yûsuf Idrîs, pp. 221-226.

Recensiones:

Ạ̣mas Al-Haduarı, Tārij as-sinimä fi Mișr, pp. 301.

Gali Šukrı (ed.), Naýib Mahfuz: ibda nuṣf qarn. Fäḍil Al-Aswad (ed.), ar-Raŷul wat-qimma, buhüt wa diräsät, pp. 302-20்.

Vol. 8, 1991: «Las primeras novelas de Naŷib Mahfüz según las criticas de la época». (En prensa).

Recensiones:

Šäkir Juṣbāk, Ahlām ḍă’r, mujtārät min qiṣaș. (En prensa).

Naŷib Mahtūz, al-Faŷr al-Kädib. (En prensa). 